held fellowships at the University of Southern California with Prof. A. B. Burg and at Harvard University with Prof. E. G. Rochow. He then remained at Harvard, first as instructor and then as assistant professor, until he returned to England in 1962. He is widely known for his work on the synthesis of organometallic compounds, particularly in the field of the carbonyl complexes and fluorocarbon derivatives of the transition metals, and for his use of modern physical methods in the determination of molecular structure. He has published a monograph on "Hydrogen Compounds of the Group IV Elements", more than eighty research papers and numerous review articles, and has recently become co-editor, with Prof. R. West of Wisconsin, of Advances in Organometallic Chemistry, to be published annually by the Academic Press.

Theoretical Physics at Durham: Prof. B. H. Bransden

Following the establishment of a chair of theoretical physics at the Durham Division of the University of Durham, Dr. Bransden, of the University of Glasgow, has been appointed the first holder as from October 1 . Dr. Bransden graduated in 1945 from University College, London, with a first-class honours degree in mathematics and physics. After a short period in industry he entered the Department of Applied Mathematics of University College as a research student and obtained his Ph.D. in 1950. From 1951 until 1955 he was a lecturer in theoretical physics at Queen's University, Belfast, and since 1955 has been successively lecturer and then senior lecturer in natural philosophy at Glasgow. $\mathrm{He}$ was a research associate at CERN in the session 1960-61. Dr. Bransden's research interests have included light nuclear scattering, and, more recently, pion-nucleon, and pionpion scattering, and the $K^{*}$ resonance. He has published many scientific papers on these subjects and is the leader of an active research group.

\section{British Scientific Instrument Research Association :}

Mr. S. S. Carlisle

Mr. S. S. CaRLISLe has been appointed director of the British Scientific Instrument Research Association (SIRA). The oldest of the co-operative research associations, SIRA has grown rapidly in recent times, having doubled its staff and income over the past seven years.

Mr. Carlisle, who takes up his appointment on November 1, has been with the British Iron and Steel Research Association since 1946. He became head of its South Wales Laboratories in 1954, returning to the London Laboratories four years later as head of the Physics Department. He became an assistant director of research in 1960. Mr. Carlisle's chief concern in recent years has been the development of the Physics Department's longrange research and development activities in such fields as strip handling by new techniques of fluid cushioning which resulted in development of the Hover Pulley, in-line product inspection technology for modern fast steel manu. facturing processes, development of new composite materials such as fibre-reinforced steels and composite coatings. He has also been responsible for co-ordination of work on automation and its application in industry. Mr. Carlisle is a vice-president of the Society of Instrument Technology and has been recently elected to the Council of the Institution of Electrical Engineers.

\section{U.S. Funds for Research and Development}

A frivar report on a survey of research and development funds and scientists and engineers in 1960, issued by the National Science Foundation as NSF 63-7 in the Survey of Science Resources Series, puts expenditure by industrial firms on researeh and development at 10,500 million dollars out of a total of 14,000 million dollars, an increase of 10 per cent on 1959 , and nearly three times the total for 1953 (Research and Development in Industry,
1960-Final Report on a Survey of $R$ and $D$ Funds and $R$ and $D$ Scientists and Engineers. Pp. xii +118 . Washington, D.C.: Government Printing Office, 1963. 65 cents). Of this 10,546 million dollars, 385 million dollars (4 per cent) was spent on basic research, 2,062 million dollars (20 per cent) on applied research, and 8,100 million dollars ( 76 per cent) on development; 4,359 million dollars derived from company sources and 6,117 million dollars from the Federal Government. More than 9,000 million dollars was expended by companies with 5,000 or more employees, and almost another 900 million dollars by firms of 1,000 4,999 employees. Federal funds for such research were 8 per cent higher than in 1959 and more than four times the comparable total in 1953. Companyfinanced research and development was 11 per cent higher than in 1959 and double that in 1953-chemicals and allied products ( 848 million dollars), electrical equipment and communication ( 816 million dollars), motor vehicles and other transport equipment (660 million dollars), and machinery (584 million dollars), accounting for 64 per cent of the 1960 total. The survey indicated that the number of companies with research and development programmes did not appreciably change between 1959 and 1960 . The 300 firms with the largest programmes in terms of dollars accounted for 92 per cent of the funds for industrial research and development. About three-fifths of the basic research was in the physical and mathematical sciences, one-fifth in the engineering sciences and the remainder in the biological and other sciences. Guided missiles, communication equipment and electronic components and aircraft and parts accounted for 5,500 million dollars out of the 10,200 million dollars utilized for applied research and development. The full-time equivalent of 307,300 scientists and engineers employed in industrial firms on research and development in January 1961 was nearly two-fifths of the total employed in the industrial sector; 85,500 were employed on aircraft and missiles, 72,200 in electrical equipment and communications, 34,400 on chemicals and allied products, and 31,700 on machinery. of the total, 79 per cent were employed by firms with 5,000 or more employees, and 10 per cent in companies with less than 1,000 employees. The average expenditure per scientist or engineer in research and development in 1960 was 35,000 dollars compared with 34,900 dollars in 1959, the average figure varying with the size of the firm, from 38,900 dollars in firms with 5,000 or more employees to 19,100 dollars in firms employing less than 1,000 .

\section{U.S. Federal Funds for Science}

IN the note on Federal Funds for Science on p. 1144 of the June 22 issue of Nature, the figure of 12,300 million dollars represents the anticipated expenditure on research and development and on plant for that purpose (and not for plant only as stated), the 14,400 million dollars being the amount obligated for these purposes. The figure of 368 million dollars is the increase authorized by Congress over the amount originally in the budget for 1963 and not, as stated, the increase in the amount for the Department of Defence, which was 1,010 million dollars, the largest increase over 1962 reported being 2,000 million dollars for the space programme administered by the National Aeronautics and Space Administration.

\section{Primary and Secondary Education in Britain}

IN a written answer in the House of Commons on August 1, the Parliamentary Secretary to the Ministry of Education, Mr. C. Chataway, stated that, during the past year, the Curriculum Study Group had been assisting the Secondary School Examinations Council to establish the new Certificate of Secondary Education examinations. The Group was also collaborating with the Nuffield Foundation in their projects for improving science and mathematics teaching and helping to organize the pilot scheme for teaching foreign languages in the primary 